\title{
Leksikon Perikanan di Danau Diatas
}

\section{The Fishing Lexicon in Lake Diatas}

\author{
Silvia Nilmayani, Rona Almos, Reniwati \\ ronaalmos@hum.unand.ac.id \\ Universitas Andalas Padang
}

\begin{abstract}
ABSTRAK
This paper describes the fisheries lexicon in Lake Diatas Alahan Panjang, Lembah Gumanti, Solok. Also, it explains the meaning of lexicon.

Methods and techniques for providing data use the SLC method, note-taking technique, and record technique. Data analysis methods and techniques use basic PUP techniques and HBB techniques.

It found 50 words and 21 phrases. The description of the meaning relates to the catching equipment and its parts, supporting equipment, and catches. In general, the cultural meaning of the fisheries lexicon in Lake Diatas is prohibitions. Some of the prohibitions are "manunjuak-nunjuak", "mangarensiangi", "takopue", "ka danau di tangah ari", and "bapusa-pusa duo biduak".
\end{abstract}

Keywords: Lexicon, Anthropolinguistics, Form, Meaning, Fisheries in Lake Diatas

\section{PENGANTAR}

Berbicara masalah perikanan tentunya tidak terlepas dari kegiatan seorang nelayan. Nelayan di Danau Diatas tidak hanya melakukan kegiatan saat penangkapan saja, tetapi juga semua kegiatan baik sebelum ataupun sesudah penangkapan. Kegiatan ini awalnya terbentuk karena masyarakat Alahan Panjang adalah sekelompok masyarakat yang tidak terbiasa dengan satu pekerjaan saja. Masyarakat di sana cenderung melakukan lebih dari satu bidang pekerjaan. Selain bekerja sebagai petani sayur mereka juga melakukan pekerjaan lain, menjadi nelayan adalah salah satunya. Peralihan ini terjadi karena masa panen yang lumayan lama. Sehingga, mereka tidak bisa berharap pada satu pekerjaan saja.

Kegiatan penangkapan yang berhubungan dengan Perikanan di Danau Diatas memiliki berbagai kosakata yang unik. Berbagai leksikon yang ada dapat dibagi menjadi beberapa bagian. Bagian-bagian tersebut terdiri dari leksikon pada peralatan penangkapan dan bagian-bagiannya, perlengkapan pendukung, serta hasil tangkapan.

Kegiatan penangkapan di Danau Diatas dilakukan dengan cara tradisional. Dalam hal penangkapan, Masyarakat nelayan menggunakan bahasa Minangkabau daerah setempat. Penggunaan bahasa tersebut tentunya memunculkan berbagai leksikon yang unik, khususnya mengenai leksikon perikanan. Leksikon yang muncul merupakan sebuah kekayaan bahasa yang dimiliki masyarakat. Selain itu, berbagai kosa kata pada leksikon perikanan tentunya menjadi sebuah kekayaan budaya yang dimiliki oleh masyarakat. 
Selain menggunakan peralatan tradisional ternyata terdapat nelayan "nakal" yang menggunakan peralatan modern, seperti sentron, putas, dan sebagainya. Perkembangan zaman menjadi salah satu faktor yang mempengaruhi penggunaan peralatan berbahaya itu. Semakin berkembangnya zaman maka kebutuhan hidup semakin tinggi. Masyarakat akan lebih memilih hal yang praktis dan menghasilkan tanpa memandang efek buruk yang ditimbulkan.

Penggunaan peralatan penangkapan modern seperti di atas dikhawatirkan akan membuat kurangnya pengetahuan masyarakat mengenai bahasa lokal. Kurangnya pengetahuan terhadap bahasa lokal bisa menyebabkan hilangnya penggunaan bahasa lokal. Hal ini tentunya juga berdampak pada hilangnya sebuah kebudayaan masyarakat.

\section{KERANGKA TEORI DAN METODOLOGI}

Menurut Chaer (Chaer, 2007), leksikologi dan leksikografi adalah dua buah kegiatan dalam linguistik yang saling berkaitan satu sama lain. Leksikologi merupakan kajian yang bersifat ilmiah. Sedangkan leksikografi adalah bersifat kegiatan praktik walaupun tidak terlepas dari ilmiah. Urutan kegiatan keduanya tidak bisa ditukar atau dibalik, sebab kegiatan leksikografi tidak bisa dilakukan tanpa terlebih dahulu dilakukan kajian leksikologi.

Leksikologi adalah bidang ilmu linguistik yang mengambil leksikon sebagai objek kajiannya. Pakar yang melakukan kegiatan ini dikenal dengan seorang leksikolog. Tahap selanjutnya setelah kegiatan leksikologi adalah kegiatan leksikografi. Leksikografi adalah kegiatan menulis dan menyusun secara alfabetis hasil kajian leksikologi. Pakar yang melakukan kegiatan ini dikenal leksikograf. Leksikograf akan menghasilkan kerja leksikografi berwujud sebuah kamus.

Sehubungan dengan leksikologi sebagai ilmu tentang leksikon, Chaer (Chaer, 2007) mengatakan bahwa istilah leksikon berasal dari kata Yunani kuno, yaitu lexicon yang berarti 'kata', 'ucapan' atau cara berbicara. Leksikon adalah komponen bahasa yang memuat semua informasi tentang makna dan pemakaian kata dalam bahasa. Leksikon merupakan kekayaan kata yang dimiliki seorang pembicara, penulis atau suatu bahasa, kosakata, perbendaharaan kata. Leksikon juga merupakan daftar kata yang disusun seperti kamus, tetapi dengan penjelasan yang singkat dan praktis (Kridalaksana, 2008).

Di sisi lain, penelitian terhadap leksikon perikanan baik darat maupun laut telah pula dilakukan. Penelitian tersebut dijadikan model baik metodologi maupun langkah atau teknik penelitian ini. Kajian ekolinguistik telah dilakukan terhadap leksikon perikanan darat di Rawa Pening Ambarawa, Jawa Tengah oleh Dita Oktiana Puspita Sari (Sari, 2015) dan di Danau Sentarum, Kapuas Hulu oleh Anggi Noviyanti (Noviyanti, Muzammil, \& Syahrani, 2018). Sementara itu, penelitian terhadap leksikon perikanan laut telah dilakukan di Tarakan (Aji, 2010), di Sibolga (Sitanggang, 2018), dan Kepulauan Riau (Dhuhani, 2018).

Di samping itu, penelitian leksikon juga dilakukan terhadap bidang pertanian persawahan (Ladyanna, Almos, Hidayat, \& Seswita, 2018), bidang psikologi khususnya emosi (Bata, Suyoto, \& Pranowo, 2015), pengobatan tradisional (Rona \& Pramono, 2015), dan pengembangan leksikon yang bersumber dari manuskrip (Almos, Pramono, Hidayat, \& Seswita, 2017). 
Metode dan teknik pada penelitian ini dibagi ke dalam dua tahapan. Pada tahap penyediaan data digunakan metode simak. Teknik dasar yang digunakan adalah teknik sadap. Teknik ini dilakukan pada saat pengambilan dokumentasi. Metode simak memiliki teknik lanjutan berupa teknik simak libat cakap (SLC). Teknik ini melibatkan peneliti dalam percakapan bersama narasumber. Selanjutnya, untuk keakuratan data juga digunakan teknik catat dan teknik rekam. Peneliti mencatat sekaligus merekam menggunakan tape recorder ataupun alat recording lainnya.

Tahap selanjutnya yang dilakukan setelah semua data terkumpul adalah analisis data. Penelitian ini menggunakan analisis data dengan metode padan yang dikemukakan oleh Sudaryanto (Sudaryanto, 1993). Metode padan merupakan metode yang alat penentunya di luar, terlepas dan tidak menjadi bagian dari bahasa (langue) yang bersangkutan. Metode padan yang digunakan adalah metode padan translasional. Penggunaan metode ini dikarenakan objek penelitian menggunakan bahasa Minangkabau dialek masyarakat setempat, sehingga perlu diterjemahkan ke dalam bahasa Indonesia. Teknik dasar yang dipakai adalah teknik pilah unsur penentu (PUP), pada teknik ini penulis memilah data yang akan dianalisis. Teknik lanjutannya adalah teknik hubung banding membedakan (HBB), teknik ini bertujuan untuk membedakan bentuk kosakata yang satu dengan yang lainnya.

\section{HASIL DAN PEMBAHASAN}

Alam tidak diciptakan begitu saja, seperti halnya danau. Danau merupakan salah satu sumber kekayaan alam yang melimpah. Di dalamnya terdapat berbagai hasil yang dapat mencukupi kehidupan manusia. Hasil tersebut seperti ikan, kerang, dan lainnya.

Melihat kenyataan tersebut, nelayan di Danau Diatas mengambil peluang untuk memanfaatkan keberadaan danau dan hasilnya. Nelayan berupaya untuk mendapatkan hasil danau dengan melakukan kegiatan penangkapan. Kegiatan penangkapan tersebut, terbagi ke dalam peralatan penangkapan dan bagian-bagiannya, perlengkapan pendukung, serta hasil tangkapan. Hal ini adalah bagian-bagian yang sangat penting dan saling berhubungan dalam perikanan di Danau Diatas.

Berdasarkan hal di atas, maka pembahasan mengenai leksikon perikanan di Danau Diatas Alahan Panjang Kecamatan Lembah Gumanti Kabupaten Solok pada bab ini berfokus pada bentuk satuan lingual berupa kata dan frasa. Selanjutnya dalam penelitian ini juga dibahas mengenai makna dari masing-masing leksikon. Makna yang ditemukan dalam penelitian ini terdiri dari 3 jenis, yaitu makna leksikal, makna gramatikal, dan makna kultural (makna yang didapat dari hasil wawancara bersama informan). Hasil penelitian di lapangan menunjukkan bahwa tidak semua leksikon perikanan mengandung ketiga makna tersebut.

Berdasarkan penjelasan di atas, maka pada penelitian ini akan diuraikan dan dijelaskan satu persatu mengenai bentuk satuan lingual dan makna yang terdapat pada leksikon perikanan di Danau Diatas Kanagarian Alahan Panjang Kecamatan Lembah Gumanti Kabupaten Solok.

Kata pada leksikon perikanan di Danau Diatas terbentuk dari morfem bebas dan morfem terikat.

Tabel 1. Kata pada leksikon perikanan

\begin{tabular}{ccc}
\hline No & Leksikon & Keterangan \\
\hline 1. & awue & Morfem bebas \\
2. & batu & Morfem bebas
\end{tabular}


Jurnal Elektronik WACANA ETNIK - Vol 7 No 2 Oktober 2019, (119-127) p ISSN 2089-8746, e ISSN 2302-7142

\begin{tabular}{|c|c|c|}
\hline 3. & biduak & Morfem bebas \\
\hline 4. & bot & Morfem bebas \\
\hline 5. & celenang & Morfem bebas \\
\hline 6. & cepuik & Morfem bebas \\
\hline 7. & congkok & Morfem bebas \\
\hline 8. & daun & Morfem bebas \\
\hline 9. & galah & Morfem bebas \\
\hline 10. & jeket & Morfem bebas \\
\hline 11. & juaran & Morfem bebas \\
\hline 12. & kajai & Morfem bebas \\
\hline 13. & karamba & Morfem bebas \\
\hline 14. & kayuah & Morfem bebas \\
\hline 15. & ladiang & Morfem bebas \\
\hline 16. & lampuang & Morfem bebas \\
\hline 17. & langkitang & Morfem bebas \\
\hline 18. & lantak & Morfem bebas \\
\hline 19. & lapun & Morfem bebas \\
\hline 20. & limbek & Morfem bebas \\
\hline 21. & lokan & Morfem bebas \\
\hline 22. & lukah & Morfem bebas \\
\hline 23. & malukah & Morfem terikat + morfem bebas \\
\hline 24. & mambangkik & Morfem terikat + morfem bebas \\
\hline 25. & mamukek & Morfem terikat + morfem bebas \\
\hline 26. & manangguak & Morfem terikat + morfem bebas \\
\hline 27. & mangatue & Morfem terikat + morfem bebas \\
\hline 28. & mangayie & Morfem terikat + morfem bebas \\
\hline 29. & mangayuah & Morfem terikat + morfem bebas \\
\hline 30. & manggalah & Morfem terikat + morfem bebas \\
\hline 31. & manjojo & Morfem terikat + morfem bebas \\
\hline 32. & maracik & Morfem terikat + morfem bebas \\
\hline 33. & mawantek & Morfem terikat + morfem bebas \\
\hline 34. & nangga & Morfem bebas \\
\hline 35. & panjaik & Morfem bebas \\
\hline 36. & paku & Morfem bebas \\
\hline 37. & pangga & Morfem bebas \\
\hline 38. & papuang & Morfem bebas \\
\hline 39. & patue & Morfem bebas \\
\hline 40. & pensi & Morfem bebas \\
\hline 41. & pisau & Morfem bebas \\
\hline 42. & saluik & Morfem bebas \\
\hline 43. & saringan & Morfem bebas \\
\hline 44. & senter & Morfem bebas \\
\hline 45. & tambang & Morfem bebas \\
\hline 46. & tangkai & Morfem bebas \\
\hline 47. & timbo & Morfem bebas \\
\hline 48. & tingau & Morfem bebas \\
\hline 49. & tubatu & Morfem bebas \\
\hline 50. & umpan & Morfem bebas \\
\hline
\end{tabular}

Berdasarkan hasil penelitian, berikut ini ditampilkan leksikon perikanan di Danau Diatas yang berbentuk frasa.

Tabel 2. Frasa pada leksikon perikanan

\begin{tabular}{ccc}
\hline No & Leksikon & Keterangan \\
\hline 1. & banang saringan & Frasa endosentrik \\
2. & ikan kalai & Frasa endosentrik \\
3. & ikan kapiyek & Frasa endosentrik \\
4. & ikan kulari & Frasa endosentrik \\
5. & ikan minyak & Frasa endosentrik \\
6. & ikan nila & Frasa endosentrik \\
7. & ikan paweh & Frasa endosentrik \\
8. & ikan rayo & Frasa endosentrik \\
9. & kayie rangguik & Frasa endosentrik \\
10. & kain saruang & Frasa endosentrik \\
11. & mantel plastik & Frasa endosentrik \\
12. & pangguluang banang & Frasa endosentrik \\
13. & plastik unjuik & Frasa endosentrik \\
14. & pukek mambanan & Frasa endosentrik \\
15. & pukek sarawai & Frasa endosentrik \\
16. & pukek timbue & Frasa endosentrik \\
17. & tali kabek & Frasa endosentrik \\
18. & tali punco & Frasa endosentrik \\
19. & tangguak kadok & Frasa endosentrik \\
20. & tangguak kaik & Frasa endosentrik \\
21. & tangguakngarai & Frasa endosentrik \\
\hline
\end{tabular}


Makna leksikon perikanan di Danau Diatas digolongkan pada peralatan penangkapan dan bagianbagiannya, peralatan pendukung, hasil tangkapan, serta aktivitas nelayan lainnya. Adapun penjelasan mengenai makna tersebut adalah sebagai berikut.

1. galah

Galah $n$ tongkat yang panjang untuk menjolok buah-buahan, menolak perahu, menjemur pakaian, dan sebagainya (Burhanuddin, 2009:228). Galah merupakan alat sejenis tombak yang digunakan untuk menangkap limbek maupun ikan yang berukuran lebih besar. Panjang galah berkisar dua setengah meter atau lebih. Alat ini memiliki mata pisau pada bagian ujungnya. Jumlah mata pisau pada ujung galah tidak boleh genap, jumlah mata pisau tersebut harus ganjil. Jumlah ganjil diyakini nelayan dapat memberikan peruntungan saat penangkapan.

Nelayan di danau di atas biasanya menggunakan atau memasang mata galah berjumlah tiga. 3 buah mata galah atau mata pisau tersebut memiliki panjang sekitar $15 \mathrm{~cm}-20 \mathrm{~cm}$ pada masing-masingnya.

"Galah tu harus mato tigo ndak bulaih mato duo."

'Galah yang digunakan harus bermata dua'

\section{2. kayie rangguik}

Kayie rangguik merupakan peralatan penangkapan ikan yang tidak memiliki tangkai, dan pada bagian benangnya hanya terdapat mato kayie dan tubatu. Kayie rangguik memiliki panjang sekitar 7 meter atau lebih, tergantung dari kebutuhan nelayan. Fungsi dari kayie rangguik tersebut adalah untuk menangkap berbagai jenis ikan.

Kayie rangguik memiliki bentuk yang sama seperti benang layangan yang digulung. Alat penangkapan jenis ini diberi nama kayie rangguik, karena dalam proses penangkapannya dilakukan dengan cara dirangguik 'direnggut' seperti benang layangan.

"Itu kayie rangguik nah, indak banang lalang tu do."

'Itu kayie ranggguik bukan benang layangan'

3. pukek

Pukek n jaring besar dan panjang untuk menangkap ikan (Burhanuddin, 2009:640). Pukek $\rightarrow$ peralatan penangkapan berbentuk persegi panjang, difungsikan untuk menangkap berbagai jenis ikan dan udang, serta digunakan untuk penangkapan dengan kapasitas yang lebih banyak.

Pukek memiliki jenis yang beragam seperti: (1) pukek timbue adalah jenis pukek yang dipasang dipermukaan air, dengan panjang sekitar 25 meter atau lebih. Batu dipasang di bagian ujung dan pangkal pukek. Nama pukek timbue diambil dari pemasangannya yang timbul di permukaan air (2) pukek sarawai adalah jenis pukek yang dipasang satu jengkal dari permukaan air, memiliki panjang sekitar 50 meter atau lebih. Batu dipasang disetiap lampuang (3) pukek mawang yaitu pukek yang dipasang 2 meter dari permukaan air, memiliki panjang 50 meter atau lebih. Batu dipasang disetiap lampuang (4) pukek mambanan adalah jenis pukek yang dipasang sampai dasar air, memiliki panjang 50 meter atau lebih. Batu dipasang di setiap lampuang, ukuran batu sebesar ukuran telur ayam. Penamaan pukek mambanan oleh masyarakat setempat diambil dari cara pemasangannya yang berada pada dasar danau dan dibanaman 'dibenamkan'. 
"Pukek nan dibanaman ka dalam danau tu namonyo pukek mambanan nah."

'Pukek mambanan adalah pukek yang cara penggunaannya dibenamkan ke dasar danau.'

\section{4. tangguak kadok}

Tangguak kadok adalah jenis tangguak yang memiliki bentuk saringan yang rapat, digunakan untuk menangkap ikan dan bada. Tangguak kadok memiliki ukuran panjang 1 meter atau lebih. Tangguak jenis ini memiliki ukuran saringan yang bervariasi, baik kecil ataupun kecil. Ukuran yang besar tentunya memiliki kapasitas yang lebih besar pula, dan sebaliknya. Peralatan ini disebut dengan tangguak kadok karena memiliki bentuk saringan yang kadok 'rapat'.

“Tangguak kadok tadi ma nyo Robi?.”

'Di mana tangguk kadok tadi Robi?'

\section{5. tingau}

Tingau $n$ alat penjerat mata jala (Burhanuddin, 2009:827). Tingau adalah alat berbentuk jarum, berlubang di bagian tengah, terbuat dari plastik, bambu ataupun tanduk rusa, yang digunakan sebagai penyulam pukek.

Tingau adalah peralatan kelengkapan yang digunakan untuk menyulam pukek. Tingau berbentuk seperti jarum besar yang memiliki lubang di tengahnya. Benang pukek yang akan dirajut, harus dililitkan terlebih dahulu pada bagian pengait yang berada di tengah tingau. Tingau terbuat dari bambu, plastik, atau tanduk rusa.

“Kini tingau lah nyo bali se di urang, lah jarang nan mambuek surangnyo."

'Sekarang orang lebih suka membeli tingau daripada membuatnya sendiri.'

\section{6. ikan kapiyek}

ikan kapiyek adalah ikan berwarna perak. Masyarakat mengistilahkan Ikan kapiyek, karena jenis ikan ini memiliki warna tubuh yang dominan berwarna perak. Hal itu tentunya sangat berbeda dari warna ikan kebanyakan. Ikan kapiyek memiliki bentuk tubuh yang lebar serta memiliki bagian kepala yang pendek. Peralatan yang digunakan untuk menangkap ikan kapiyek adalah pukek, kayie rangguik.

"Ikan kapiyek ko lah payah mandapek an nyo mah."

'Ikan kapiyek ini sekarang sulit untuk menangkapnya.'

\section{7. limbek}

Limbek $n$ ikan air tawar, berpatil, badannya licin, bagian mulutnya bersungut, warna punggungnya hitam, bagian perutnya berwarna putih agak kelabu; lele. Limbek adalah ikan tidak bersisik, berwarna hitam, berlendir dan bisa menyengat.

Limbek adalah jenis ikan yang licin dan berlendir, sehingga susah untuk mendapatkannya. Jenis limbek di Danau Diatas memiliki ukuran yang beragam, kecil, menengah, dan besar. Ikan jenis ini memiliki 2 panyangek atau patil yang berada di bagian kiri dan kanan kepalanya. Kedua patil pada limbek berbentuk seperti antena tv. Patil berfungsi untuk melumpuhkan lawan, dengan cara menyengatnya. Limbek ditangkap dengan menggunakan peralatan penangkapan seperti, galah.

"Bak kecek urang lah samo jo mamintak sisiak ka limbek mah."

'Kalau kata orang ini sama dengan meminta sisik ikan limbek.' 
8. lukah

Lukah $n$ alat yang terbuat dari bambu untuk menangkap ikan atau belut dengan cara meletakkannya dalam air dangkal (Burhanuddin, 2009:507). Lukah adalah peralatan penangkapan ikan yang berfungsi untuk menangkap atau mengurung ikan, yang terbuat dari bambu atau jaring kasar.

Lukah memiliki jenis yang beragam tergantung dari kebutuhan nelayan itu sendiri. Beberapa jenis lukah tersebut ialah lukah untuk menangkap dan lukah untuk mengurung ikan hasil tangkapan. Nelayan biasanya mengurung ikan dalam lukah. Hasil yang didapatkan pada hari tersebut kurang banyak, sehingga perlu dikurung terlebih dahulu untuk kemudian besoknya ditambahkan dengan ikan tangkapan baru.

"Sia nan punyo lukah ko go?”

'Siapa yang punya lukah ini?'

\section{9. malukah}

Malukah v memasang lukah (Burhanuddin, 2009:507). Malukah adalah kegiatan penangkapan dengan menggunakan lukah. Pada nelayan di Danau Diatas, malukah tidak hanya diartikan sebagai kegiatan menangkap ikan, tetapi juga sebagai kegiatan mengurung untuk mengurung ikan. Malukah biasanya dilakukan pada bagian danau yang tidak terlalu dalam. Hal itu karena bentuk dan ukurannya yang tidak terlalu besar.

Leksikon malukah merupakan bentuk kompleks yang mengandung morfem terikat. Leksikon tersebut terbentuk dari kata dasar lukah mendapat imbuhan prefiks \{ma-\}. Menurut Ayub (1993:46) afiksasi tersebut mengakibatkan perubahan kelas kata dari nomina menjadi verba. Bentuk kompleks pada leksikon malukah memiliki arti 'melakukan kegiatan malukah'.

"Malukah jan di ayie nan dalam.”

'Jangan me-lukah di air yang dalam.'

\section{Mangatue}

Mangatue adalah kegiatan pembuatan pukek dengan cara menyulamnya. Mangatue merupakan aktivitas membuat pukek, yaitu dengan cara menyulamnya dengan menggunakan tingau. Aktivitas mangatue membutuhkan fokus, kesabaran dan kekuatan otot tangan. Karena tangan harus terus bekerja dengan cepat.

Leksikon mangatue merupakan bentuk kompleks yang mengandung morfem terikat. Leksikon tersebut terbentuk dari kata dasar atue mendapat imbuhan prefiks \{mang-\}. Afiksasi pada kata tersebut tidak membuat perubahan kelas kata. Bentuk kompleks pada leksikon mangatue memiliki arti 'melakukan kegiatan mangatue (menyulam)'.

"Kok mangatue tu harus pakai tingau nah."

'Jika ingin menyulam harus menggunakan alat yang bernama tingau.'

Secara umum makna kultural pada leksikon perikanan di Danau Diatas adalah lebih kepada laranganlarangan atau pantangan. Larangan-larangan tersebut harus dipatuhi oleh seluruh nelayan. Tidak hanya nelayan, masyarakat sekitar dan wisatawan yang datang ke danau juga harus mematuhi larangan-larangan tersebut. 
Berdasarkan hasil wawancara dengan masyarakat nelayan di Danau Diatas, makna kultural berupa larangan-larangan tersebut di antaranya adalah sebagai berikut:

1. larangan manunjuak-nunjuak

Ketika sedang berada di danau, sangat dilarang bagi pengunjung baik yang hendak menangkap ikan maupun berwisata untuk manunjuak-nunjuak. Larangan tersebut karena bisa saja apa yang terlihat adalah tipu daya iblis danau.

Contoh tuturan manunjuak-nunjuak yaitu "eh aa tu nan bakilek bantuaknyo di tangah danau tu?" 'eh, apakah yang berkilau di tengah danau itu?' Jika hal seperti ini dilakukan bisa membuat seseorang jadi sakit bahkan gila.

2. larangan mangarensiangi

Mangarensiangi berarti berperilaku tidak sopan saat berada di danau. Perilaku tidak sopan tersebut dapat berupa apa saja yang dapat mengganggu makhluk lain penghuni danau. Jika larangan ini dilanggar, maka akan terjadi bencana sepeti angin topan, badai. Hal yang sangat fatal adalah danau akan meminta tumbal. Tumbal yang diminta adalah lima atau tujuh ekor kerbau putih, jika tumbal tersebut tidak segera diberikan danau akan mengambil korbannya sendiri yaitu manusia.

\section{3. larangan takopue}

Larangan lain saat berada di danau adalah takopue. Takopue adalah perilaku sombong menghendaki sesuatu yang berbahaya "kalua lah ikan gadang nan sagadang biduak, ndak takuik den do", "keluarlah ikan yang besar,saya tidak takut'. Jika larangan ini dilanggar akan berakibat fatal, sebab ikan yang dipanggil akan muncul dan tentunya bisa memangsa orang yang takopue.

4. larangan ka danau di tangah ari

Larangan $k a$ danau di tangah ari 'ke danau di tengah ari' merupakan larangan yang harus dipatuhi nelayan ataupun wisatawan, karena pada saat itu banyak jin yang berkeliaran. Jika larangan tersebut dilanggar akan mengakibatkan seseorang terkena penyakit tasapo (kesurupan). Penyakit tersebut adalah penyakit yang disebabkan oleh masuknya jin danau ke tubuh seseorang.

\section{5. larangan urang bapusa-pusa duo babiduak}

Masyarakat di Alahan Panjang mempercayai bahwa tidak boleh bagi orang yang bapusa-pusa duo 'berpusar-pusar dua' babiduak. Mereka hanya boleh melakukan penangkapan di pinggir danau. Jika mereka melanggar ketentuan tersebut, maka akan terjadi kecelakaan seperti tiba-tiba biduk karam dan membahayakan keselamatan nelayan.

\section{PENUTUP}

Leksikon perikanan di Danau Diatas Kanagarian Alahan Panjang Kabupaten Solok terdapat bentuk leksikon yang berupa kata dan frasa. Bentuk leksikon berupa kata terdiri atas morfem bebas dan morfem terikat. Jenis frasa pada penelitian ini berupa frasa endosentrik atributif, karena banyak kata yang hanya sebagai atribut dan tidak menjadi bagian yang penting dari sebuah frasa. 
Terdapat tiga jenis makna pada penelitian ini yaitu makna leksikal, makna gramatikal, dan makna kultural, namun tidak semua leksikon yang mengandung ketiga makna tersebut. Pada penelitian ini terdapat makna kultural berupa larangan-larangan yang harus dipatuhi oleh nelayan maupun wisatawan. Larangan tersebut adalah berupa larangan manunjuak-nunjuak, larangan mangarensiangi, larangan takopue, larangan ka danau di tangah ari, dan larangan bapusa-pusa duo.

\section{DAFTAR PUSTAKA}

Aji, D. C. (2010). LEKSIKON ETHNO-FISHERY DALAM KEARIFAN LOKAL SUKU BUGIS DI TARAKAN, KALIMANTAN TIMUR (Sebuah Kajian Etnolinguistik). Adabiyyāt: Jurnal Bahasa Dan Sastra, 9(2), 272. https://doi.org/10.14421/ajbs.2010.09204

Almos, R., Pramono, Hidayat, H. N., \& Seswita. (2017). TEKS KLASIK SEBAGAI SUMBER PENGEMBANGAN LEKSIKOGRAFI MINANGKABAU. Wacana Etnik, 6(2).

Bata, J., Suyoto, S., \& Pranowo, P. (2015). LEKSIKON UNTUK DETEKSI EMOSI DARI TEKS BAHASA INDONESIA. In Seminar Nasional Informatika (SEMNASIF) (Vol. 1). Retrieved from http://jurnal.upnyk.ac.id/index.php/semnasif/article/view/1383

Chaer, A. (2007). Leksikologi dan Leksikografi Indonesia. Jakarta: Rineka Cipta.

Dhuhani, A. (2018). Ekoleksikon Perikanan dalam Bahasa Melayu Kepulauan Riau Desa Tanjung Kelit Kecamatan Senayang Kabupaten Lingga Kepulauan Riau. Universitas Sumatera Utara, Medan. Retrieved from http://repositori.usu.ac.id/handle/123456789/3754

Kridalaksana, H. (2008). Kamus Linguistik. Jakarta: Gramedia.

Ladyanna, S., Almos, R., Hidayat, H. N., \& Seswita. (2018). Leksikon Persawahan di Kota Padang. Puitika, 14(2), 854-817.

Noviyanti, A., Muzammil, A. R. ul, \& Syahrani, A. (2018). LEKSIKON PERIKANAN DI DANAU SENTARUM KABUPATEN KAPUAS HULU. Jurnal Pendidikan Dan Pembelajaran, 7(9). Retrieved from http://jurnal.untan.ac.id/index.php/jpdpb/article/view/28288

Rona, A., \& Pramono. (2015). Leksikon Etnomedisin dalam Pengobatan Tradisional Minangkabau. Jurnal Arbitrer, 2(1), 44-53. https://doi.org/10.25077/ar.2.1.44-53.2015

Sari, D. O. P. (2015). LEKSIKON PERIKANAN DI RAWA PENING AMBARAWA. Universitas Negeri Semarang, Semarang. Retrieved from https://lib.unnes.ac.id/23141/

Sitanggang, G. F. (2018). Pergeseran dan Pemertahanan Leksikon Lingkungan Kelautan dalam Bahasa Pesisir Sibolga: Kajian Ekolinguistik. Universitas Sumatera Utara, Medan. Retrieved from http://repositori.usu.ac.id/handle/123456789/15109

Sudaryanto. (1993). Metode dan Aneka Teknik Analisis Bahasa. Yogyakarta: Gajah Mada University Press. 